\title{
Circulating Lymphocyte Subpopulations in Juvenile Insulin-Dependent Diabetes
}

\section{Correction of Abnormalities by Adequate Blood Glucose Control}

\author{
J. L. Selam ${ }^{1}$, J. Clot ${ }^{2}$, M. Andary ${ }^{2}$, and J. Mirouze ${ }^{1}$ \\ ${ }^{1}$ Clinique des Maladies Métaboliques et Endocriniennes, and ${ }^{2}$ Departement d'Immunologie Cellulaire (Prof. A. Serre), \\ Hôpital Saint-Eloi, Montpellier, France
}

\begin{abstract}
Summary. Circulating lymphocytes from 39 juvenile insulin dependent diabetics of recent onset were studied by six membrane marker techniques and mitogen stimulation. Well controlled $(n=14)$ were grouped separately from poorly controlled $(n=25)$ patients. The total lymphocyte counts were not different from 50 control subjects. The percentage of $T$ cells detected by erythrocyte rosettes and B-cells detected by erythrocytes - antibody - complement rosettes was significantly decreased only in poorlycontrolled diabetics $(64.1 \pm 1.3$ and $9.7 \pm 1.8$, vs $71.0 \pm 1.0$ and $15.3 \pm 0.6$ in controls). Cells bearing receptors for the Fc fragment of IgG immunoglobulins were decreased in both groups. Mitogen stimulation was not different from controls but was significantly lower in poorly controlled than in well controlled diabetics. Optimal blood glucose control for $5 \pm$ 2 days using an external artificial pancreas led to a rapid normalisation of membrane marker values and mitogen responsiveness of lymphocytes from previously poorly controlled diabetics. Separate in vitro experiments showed that glucose had an inhibitory effect on mitogen stimulation at concentrations $\geqslant 8.3 \mathrm{mmol} / 1$ and on $\mathrm{T}$ - and B-lymphocyte numbers at concentrations $\geqslant 55.6 \mathrm{mmol} / \mathrm{l}$. DL 3-hydroxybutyrate tested at 17.1 and $34.2 \mathrm{mmol} / \mathrm{l}$ only depressed mitogen responsiveness. Such results suggest a rapidly reversible $\mathrm{T}$-cell defect closely linked to the existing metabolic disturbances.
\end{abstract}

Key words: Juvenile diabetes, insulin dependent diabetes, ketotic diabetes, hyperglycaemia, cellular immunity, lymphocyte subpopulations, artificial pancreas.
Cell-mediated immunity like heredity, virus infections [1] and humoral immunity [2] may play an important role in the aetiology of diabetes [3-6]. Studies on circulating lymphocytes in diabetics have given variable results [7-13] which may be due to differences in methodology, selection of patients or metabolic control at the time of the study. In order to re-examine these findings, we have studied circulating lymphocyte subpopulations in the juvenile insulin dependent type of diabetes which may be related aetiologically to immunological factors $[14,15]$. Lymphocyte subpopulations were investigated by surface membrane markers, using six different methods, and by the proliferative responses to various mitogens. The results were related to the quality of diabetic control obtained by conventional insulin therapy and, in some cases, by the external artificial pancreas, which is now the best way of maintaining optimal blood glucose control [16]. In addition, the effects of glucose and 3-hydroxybutyrate on various lymphocyte properties were studied in vitro.

\section{Materials and Methods}

\section{Patients}

Thirty nine juvenile insulin dependent diabetics (JOD; mean age 19 years, $\mathrm{SEM} \pm 1$ ) of recent onset (mean duration 1.9 months, $\mathrm{SEM} \pm 0.3)$ were studied. Well controlled $(\mathrm{n}=14)$ were grouped separately from poorly controlled $(n=25)$ patients (Table 1$)$ : diabetes was considered well controlled when mean blood glucose (calculated from 8 diurnal samples taken at $07.00,09.00,12.00$, $14.00,18.00,20.00,00.00,04.00$ ) lay below $11.1 \mathrm{mmol} / 1$ and ketonuria had been absent for at least 3 days before the experiment. No patients were taking any drug known to interfere with lymphocyte function. Eight patients from the poorly controlled group were re-examined immediately following a period $(5 \pm 2$ 
Table 1. Clinical characteristics

\begin{tabular}{|c|c|c|c|c|c|c|}
\hline & & $\begin{array}{l}\text { Sex } \\
(\mathrm{M} / \mathrm{F})\end{array}$ & $\begin{array}{l}\text { Age } \\
\text { (years) }\end{array}$ & $\begin{array}{l}\text { Duration of diabetes } \\
\text { (months) }\end{array}$ & $\begin{array}{l}\text { Mean blood } \\
\text { glucose } \\
(\mathrm{mmol} / \mathrm{l})\end{array}$ & $\begin{array}{l}\text { Ketotic patients } \\
\text { (n) }\end{array}$ \\
\hline $\begin{array}{l}\text { Well controlled JOD } \\
(\mathrm{n}=14)\end{array}$ & $\begin{array}{l}\text { mean } \\
\text { SEM }\end{array}$ & $8 / 6$ & $\begin{array}{r}20 \\
2\end{array}$ & $\begin{array}{l}1.5 \\
0.3\end{array}$ & $\begin{array}{l}7.8 \\
0.6\end{array}$ & 0 \\
\hline $\begin{array}{l}\text { Poorly controlled } \\
\text { JOD }(n=25) \\
\mathrm{p}\end{array}$ & $\begin{array}{l}\text { mean } \\
\text { SEM }\end{array}$ & $22 / 3$ & $\begin{array}{r}19 \\
1 \\
\text { NS }\end{array}$ & $\begin{array}{l}2.2 \\
0.4 \\
\text { NS }\end{array}$ & $\begin{array}{l}17.1 \\
0.7 \\
<0.0001\end{array}$ & 15 \\
\hline
\end{tabular}

NS $=$ Non significant

a Means of individual blood glucose calculated from 8 diurnal samples taken at $07.00,09.00,12.00,14.00,18.00,20.00,00.00$ and 04.00

b Patients were considered ketotic when ketonuria had been present for at least 3 days before the experiment

days) of optimal blood glucose control (mean blood glucose: $5.0 \pm$ $0.1 \mathrm{mmol} / \mathrm{l}$ ) by means of an external artificial pancreas [16].

The control group included 50 sex and age matched healthy volunteers, none of them was taking any drug.

\section{Methods}

Lymphocyte Suspensions: Lymphocytes were obtained from heparinised blood, taken at 08.00 before breakfast, centrifuged $\left(400 \mathrm{~g} 30 \mathrm{~min}, 20^{\circ} \mathrm{C}\right.$ ) on a Ficoll-Hypaque gradient (density 1.077 ). The cell suspensions contained $85-95 \%$ small lymphocytes and $5-15 \%$ monocytes (as determined by peroxidase staining). The cells were washed three times in Hank's balanced salt solution and ajusted to the appropriate concentration for each method used.

Lymphocyte Membrane Markers: Six different methods were employed to enumerate T-, B-cells and cells bearing receptors for the Fc fragment of IgG immunoglobulins [17] according to techniques already reported in detail $[18,19]$.

T-lymphocytes were detected by the formation of E-rosettes and "active" E-rosettes with sheep erythrocytes (E). In addition, these cells were studied by a microcytotoxicity test using a horse anti-human-T-lymphocyte-antigen (HTLA) serum (kindly provided by J. Brochier, INSERM U 80, Hôpital Ed. Herriot, Lyon, France).

B-lymphocytes were identified by the presence of surface immunoglobulins using fluoresceinated anti-polyvalent human IgF $\left(\mathrm{ab}^{\prime}\right)_{2}$ fragments, and by rosettes with erythrocyte-antibody-complement complexes which detected cells bearing receptors for complement.

Cells bearing receptors for the $\mathrm{Fc}$ fragment of $\mathrm{IgG}$ immunoglobulins were quantitated by a rosette test using chicken erythrocytes coated with rabbit $\operatorname{IgG}$ antibodies.

Finally, monocyte contamination in each technique was assessed by peroxidase staining.

Lymphocyte Stimulation by Phytomitogens: Lymphoid cells were cultured in microtitre plates as previously described [18]. Briefly, microcultures were set up as four replicates with $2 \times 10^{5}$ cells/well in culture medium RPMI 1640 (GIBCO, New York) supplemented with $15 \%$ inactivated human $\mathrm{AB}$ serum.

In addition to unstimulated controls, lymphocyte cultures were stimulated with the following mitogens: phytohaemagglutinin (Difco, Detroit, Michigan), concanavalin A (Pharmacia, Uppsala, Sweden) and pokeweed mitogen (Grand Island Biological Co.,
Grand Island, New York). Optimal doses of mitogens were previously determined by studies using dose-response curves of lymphocyte cultures from normal donors: phytohaemagglutinin: $25 \mu \mathrm{g} / \mathrm{ml}$; concanavalin A: $25 \mu \mathrm{g} / \mathrm{ml}$; and pokeweed mitogen: $50 \mu \mathrm{g} / \mathrm{ml}$. The cultures were incubated at $37^{\circ} \mathrm{C}$ for 3 days (phytohaemagglutinin and concanavalin A) and 6 days (pokeweed mitogen). Blastogenesis was estimated by $3 \mathrm{H}$-thymidine incorporation, measured by liquid scintillation counting, as previously reported [18].

In Vitro Experiments with Glucose and DL3-Hydroxybutyrate: Rosette forming cells and cells bearing receptors for the Fc fragment of IgG immunoglobulins were counted in peripheral blood lymphocytes from healthy volunteers by mixing the usual indicators and the lymphocytes suspended during the test in medium containing various amounts of D-glucose (Prolabo, Paris) or DL3hydroxybutyrate (Boehringer Mannheim GmbH, Germany). In other experiments, normal lymphocytes were preincubated overnight with various concentrations of D-glucose or DL3-hydroxybutyrate, then washed and cultured in the presence of mitogens.

Statistical Methods: The results are expressed as mean \pm standard error of the mean (SEM). The significance of differences in the mean values between groups was tested by Student's t-test. Significant differences between the pre- and posttreatment results within the poorly controlled group were sought by Student's paired $\mathrm{t}$-test, after verification of normal distribution.

\section{Results}

Lymphocyte Membrane Markers (Table 2): The percentages of T-lymphocytes detected by formation of E-rosettes, and cells bearing receptors for the Fc fragment of immunoglobulins or for complement were significantly $(p<0.01)$ decreased in JOD when compared with controls. The percentages of monocytes stained by peroxidase were increased in JOD.

The total lymphocyte count was $1768 \pm 75$ per $\mathrm{mm}^{3}$ in the control group, and $1627 \pm 88$ per $\mathrm{mm}^{3}$ in the JOD group. The difference was not statistically significant. However, the lower total lymphocyte count observed in JOD caused a greater statistical 
Table 2. Results of lymphocyte membrane markers

\begin{tabular}{|c|c|c|c|c|c|c|c|c|c|}
\hline & & & E-RFC & HTLA $^{b}$ & $\begin{array}{l}\text { "active"" } \\
\text { E-RFC }\end{array}$ & $\operatorname{SIg}^{d}$ & $\begin{array}{l}\mathrm{EAC} \\
\mathrm{RFC}\end{array}$ & $\begin{array}{l}\text { EA } \gamma^{\mathrm{f}} \\
\text { RFC }\end{array}$ & Monocytes \\
\hline \multirow[t]{2}{*}{$\begin{array}{l}\text { Controls } \\
(n=50)\end{array}$} & $\begin{array}{l}\text { \% lymphocyte } \\
\text { Lymphocyte } \\
\text { count per } \mathrm{mm}^{3}\end{array}$ & $\begin{array}{l}\text { mean } \\
\text { SEM } \\
\text { mean } \\
\text { SEM }\end{array}$ & $\begin{array}{r}71.0 \\
1.0 \\
1253 \\
18\end{array}$ & $\begin{array}{c}75.5 \\
0.8 \\
1342 \\
12\end{array}$ & $\begin{array}{c}19.9 \\
0.9 \\
358 \\
16\end{array}$ & $\begin{array}{c}11.3 \\
0.6 \\
200 \\
10\end{array}$ & $\begin{array}{c}15.3 \\
0.6 \\
271 \\
11.5\end{array}$ & $\begin{array}{c}11.1 \\
0.5 \\
196 \\
8\end{array}$ & $\begin{array}{r}7.9 \\
0.8 \\
-\end{array}$ \\
\hline & $\begin{array}{l}\text { \% lymphocyte } \\
\text { Lymphocyte } \\
\text { count per } \mathrm{mm}^{3}\end{array}$ & $\begin{array}{l}\text { mean } \\
\text { SEM } \\
\text { mean } \\
\text { SEM }\end{array}$ & $\begin{array}{r}66.5 \\
1.1 \\
1110 \\
21\end{array}$ & $\begin{array}{r}75.8 \\
1.4 \\
1240 \\
31\end{array}$ & $\begin{array}{c}21.6 \\
1.9 \\
358 \\
12\end{array}$ & $\begin{array}{c}12.9 \\
0.9 \\
206 \\
10\end{array}$ & $\begin{array}{c}10.9 \\
1.3 \\
175 \\
13\end{array}$ & $\begin{array}{r}8.0 \\
0.7 \\
140 \\
10\end{array}$ & $\begin{array}{r}11.5 \\
1.2\end{array}$ \\
\hline $\begin{array}{l}\text { JOD } \\
(n=39)\end{array}$ & $\begin{array}{l}\text { \% lymphocyte } \\
\text { Lymphocyte } \\
\text { count per } \mathrm{mm}^{3}\end{array}$ & $\begin{array}{l}\mathrm{p} \\
\mathrm{p}\end{array}$ & $\begin{array}{l}<0.01 \\
<0.0001\end{array}$ & $\begin{array}{l}\text { NS } \\
\quad<0.01\end{array}$ & $\begin{array}{l}\text { NS } \\
\text { NS }\end{array}$ & $\begin{array}{l}\text { NS } \\
\text { NS }\end{array}$ & $\begin{array}{l}<0.001 \\
<0.0001\end{array}$ & $\begin{array}{l}<0.01 \\
<0.001\end{array}$ & $\begin{array}{l}<0.02 \\
-\end{array}$ \\
\hline \multicolumn{2}{|c|}{$\begin{array}{l}\text { Well control- \% lymphocyte } \\
\text { led JOD }\end{array}$} & mean & 70.8 & 75.9 & 19.9 & 11.1 & $12.3^{\mathrm{g}}$ & 7.8 & 9.9 \\
\hline \multirow{2}{*}{\multicolumn{2}{|c|}{$\begin{array}{l}(n=14) \\
\text { Poorly control- \% lymphocyte } \\
\text { led JOD } \\
(n=25) \\
\text { Controls w. well }\end{array}$}} & mean & $\begin{array}{r}0.9 \\
64.1\end{array}$ & $\begin{array}{r}1.1 \\
75.6\end{array}$ & $\begin{array}{r}1.2 \\
22.8\end{array}$ & $\begin{array}{r}1.4 \\
13.8\end{array}$ & $\begin{array}{l}1.9 \\
9.7 \mathrm{~g}\end{array}$ & $\begin{array}{l}1.2 \\
8.2\end{array}$ & $\begin{array}{r}1.8 \\
12.2\end{array}$ \\
\hline & & SEM & 1.3 & 1.6 & 2.4 & 1.2 & 1.8 & 0.9 & 1.6 \\
\hline \multirow{3}{*}{\multicolumn{2}{|c|}{$\begin{array}{l}\text { Controls vs Well } \\
\text { controlled JOD } \\
\text { Controls ys poorly } \\
\text { controlled JOD } \\
\text { Well vs poorly } \\
\text { controlled JOD }\end{array}$}} & $\mathrm{p}$ & NS & NS & NS & NS & NS & $<0.01$ & NS \\
\hline & & $\mathrm{p}$ & $<0.0001$ & NS & NS & $<0.05$ & $<0.001$ & $<0.01$ & $<0.01$ \\
\hline & & $\mathrm{p}$ & $<0.01$ & NS & NS & NS & NS & NS & NS \\
\hline
\end{tabular}

NS $=$ Non significant

a $T$-cells identified by formation of rosettes with sheep erythrocytes (E-rosettes)

b T-cells identified by using a horse anti-human T-lymphocyte antigen (HTLA) serum

c T-cells identified by formation of "active" E-rosettes

d B-cells identified by the presence of surface immunoglobulins (S Ig)

e B-cells identified by formation of rosettes with erythrocyte-antibody-complement complexes (EAC)

f Cells bearing receptors for the $\mathrm{Fc}$ fragment of IgG immunoglobulins identified by an erythrocyte-antibody (EA) rosette test

$\mathrm{g}$ EAC rosettes were performed in only 25 cases ( 12 well controlled and 13 poorly controlled JOD)

difference than mean percentages of rosettes forming cells. It was also observed that the lymphocyte count of cells bearing HTLA was significantly decreased in the JOD group.

Poorly controlled diabetics had a significantly lower mean proportion of E-rosettes forming cells than well controlled diabetics and controls. In the same way, poorly controlled diabetics has significantly lower mean percentages of cells bearing receptors for the $\mathrm{Fc}$ fragment of immunoglobulins and for complement when compared to the control group. In contrast, the mean percentages of cells bearing surface immunoglobulins and of monocytes were significantly increased. Finally, the proportions of lymphocyte membrane markers were not significantly different in well controlled JOD and healthy subjects except for cells bearing receptors for the $\mathrm{Fc}$ fragment of immunoglobulins.
Lymphocyte Stimulation by Phytomitogens (Table 3): No significant difference was observed between controls and JOD in the results of lymphocyte cultures stimulated by phytohaemagglutinin, concanavalin A and pokeweed mitogen. Significant differences appeared, however, when diabetics were separated according to metabolic control. Poorly controlled diabetics had lower responses to the three mitogens than well controlled diabetics. Likewise, the spontaneous thymidine incorporation in unstimulated cultures was low. No significant difference was noted between these two subgroups and the control group except a higher response of well controlled diabetics to phytohaemagglutinin and a lower response of poorly controlled diabetics to pokeweed mitogen.

Lymphocyte Markers and Mitogen Stimulation before and after Optimal Blood Glucose Control (Table 4): 
Both the percentage of E-rosettes forming cells and the response to phytohaemagglutinin stimulation were increased after blood glucose control. The values returned to normal, similar to those obtained in the control group.

In Vitro Experiments with Glucose and DL3 $\mathrm{Hy}$ droxybutyrate (Table 5): Glucose added to the medium in which rosette-tests were performed, resulted in a decrease of the mean percentages of the rosette-forming-cells. However, this effect was only noted with high concentrations of glucose $(55.6 \mathrm{mmol} / \mathrm{l})$. Tested in the same way DL3-hy-

Table 3. Results of lymphocyte stimulation by phytomitogens

\begin{tabular}{|c|c|c|c|c|c|}
\hline & \multicolumn{5}{|c|}{${ }^{3} \mathrm{H}$ Thymidine incorporation of cells } \\
\hline & \multirow{2}{*}{\multicolumn{2}{|c|}{ Unstimulated }} & \multicolumn{3}{|c|}{ Stimulated with } \\
\hline & & & PHA & ConA & PWM \\
\hline \multirow{5}{*}{$\begin{array}{l}\text { Controls } \\
(\mathrm{n}=50) \\
\text { JOD } \\
(\mathrm{n}=39)\end{array}$} & mean & 1,129 & 72,521 & 46,284 & 57,795 \\
\hline & SEM & 158 & 7,134 & 5,662 & 5,705 \\
\hline & mean & 1,286 & 70,400 & 47,928 & 46,105 \\
\hline & SEM & 238 & 8,395 & 6,297 & 4,770 \\
\hline & $\mathrm{p}$ & NS & NS & NS & NS \\
\hline Well controlled & mean & 1,788 & 102,360 & 59,690 & 57,952 \\
\hline $\operatorname{JOD}(n=14)$ & SEM & 395 & 9,640 & 3,089 & 8,273 \\
\hline Poorly controlled & mean & 1,058 & 53,146 & 40,519 & 38,955 \\
\hline JOD $(n=25)$ & SEM & 141 & 5,341 & 6,831 & 5,282 \\
\hline \multirow{3}{*}{$\begin{array}{l}\text { Controls vs well } \\
\text { controlled JOD } \\
\text { Controls vs poorl } \\
\text { controlled JOD } \\
\text { Well vs poorly } \\
\text { controlled JOD }\end{array}$} & $\mathrm{p}$ & NS & $<0.05$ & NS & NS \\
\hline & p & NS & NS & NS & $<0.05$ \\
\hline & $\mathrm{p}$ & $<0.05$ & $<0.0001$ & $<0.05$ & $<0.05$ \\
\hline
\end{tabular}

The results are expressed as mean \pm SEM of disintegration per minute (dpm)

PHA: phytohaemagglutinin

ConA: concanavalin A

PWM: pokeweed mitogen droxybutyrate at 17.1 and $34.2 \mathrm{mmol} / 1$ only produced a slight nonsignificant decrease.

The preincubation of normal lymphocytes in medium containing glucose or DL3-hydroxybutyrate, before stimulation by phytohaemagglutinin caused low proliferative responses even at low concentrations of glucose $(8.3 \mathrm{mmol} / 1)$.

\section{Discussion}

Impairment of lymphocyte numbers and function has already been reported in diabetics. A T-cell defect assessed by E-rosettes has been found by some authors $[11,13]$ but not by others $[10,12]$. Phytohaemagglutinin responsiveness has been found to be depressed in most studies $[7,9,10,13]$ especially in poorly controlled diabetics $[9,10]$. In vitro experiments $[20,21]$ showed the influence of glucose and free fatty acids on lymphocyte function. Our investigation extended to include the study of many lymphocyte membrane markers and our results show that T-cells (detected by E-rosettes) and B-cells (detected by Erythrocyte Antibody Complement rosettes) were decreased only in poorly controlled JOD. Cells bearing receptors for the Fc fragment of immunoglobulins were decreased in both well controlled and poorly controlled patients. The defect in mitogen stimulation was confirmed by using three different phytomitogens whose responses were depressed in poorly controlled diabetics when compared with well controlled diabetics. Careful selection of patients increased the reliability of our study: only juvenile insulin dependent diabetics of recent onset were chosen and well controlled were clearly grouped separately from poorly controlled patients.

Our results show that optimal blood glucose control via an artificial pancreas even if only temporary, leads to a rapid normalisation of surface marker values and mitogen stimulation of lymphocytes from

Table 4. Results of lymphocyte membrane markers and lymphocyte stimulation from patients studied before and immediately after optimal blood glucose control by an artificial pancreas

\begin{tabular}{|c|c|c|c|c|c|c|c|c|c|c|c|}
\hline & \multirow{3}{*}{ 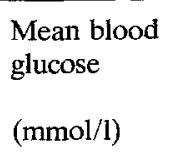 } & & \multirow[t]{3}{*}{ E-RFC } & \multirow[t]{3}{*}{ FTLA } & \multirow{2}{*}{\multicolumn{2}{|c|}{$\begin{array}{l}\text { "Active" SIg } \\
\text { E-RFC }\end{array}$}} & \multirow{3}{*}{$\begin{array}{l}\text { EAy } \\
\text { RFC }\end{array}$} & \multicolumn{4}{|c|}{${ }^{3} \mathrm{H}$ Thymidine incorporation of cells } \\
\hline & & & & & & & & Unstimulated & Stimulate & with & \\
\hline & & & & & & & & & PHA & ConA & PWM \\
\hline \multirow{5}{*}{$\begin{array}{l}\text { Before } \\
(n=8) \\
\text { After } \\
(n=8)\end{array}$} & \multirow[t]{2}{*}{$19.0 \pm 0.7^{\mathrm{a}}$} & mean & 69.0 & 76.6 & 29.8 & 15.6 & 7.6 & 749 & 64,471 & 46,514 & 51,029 \\
\hline & & SEM & 1.8 & 2.9 & 4.6 & 2.1 & 1.1 & 42 & 7,621 & 9,189 & 10,307 \\
\hline & \multirow[t]{3}{*}{$5.0 \pm 0.1^{b}$} & mean & 76.6 & 79.7 & 25.0 & 15.6 & 10.6 & 949 & 101,514 & 63,157 & 58,900 \\
\hline & & SEM & 3.4 & 4.1 & 2.2 & 1.6 & 1.5 & 133 & 9,778 & 18,012 & 14,789 \\
\hline & & $\mathrm{p}$ & $<0.05$ & NS & NS & NS & NS & NS & $<0.02$ & NS & NS \\
\hline
\end{tabular}

Means of individual blood glucose means recorded before (a) and during (b) the period of blood glucose control ( $5 \pm 2$ days) Expression of results and abbreviations as in Tables 2 and 3 
Table 5. In vitro effects of D glucose and DL 3-hydroxybutyrate on lymphocytes from healthy volunteers

\begin{tabular}{|c|c|c|c|c|c|c|c|}
\hline Addition to medium & & & E-RFC & $\mathrm{EA} \gamma-\mathrm{RFC}^{\mathrm{a}}$ & $\mathrm{PHA}^{\mathrm{b}}$ & $\operatorname{Con}^{b}$ & $\mathrm{PWM}^{\mathrm{b}}$ \\
\hline & 0 & mean $^{c}$ & 72.7 & 11.5 & 74,625 & 48,125 & 57,202 \\
\hline & & SEM & 1.8 & 0.8 & 7,831 & 6,201 & 6,008 \\
\hline \multirow{9}{*}{$\begin{array}{l}\text { Glucose } \\
(\mathrm{mmol} / \mathrm{l})\end{array}$} & & & & & & & \\
\hline & 8.3 & mean & 72.1 & 11.7 & $50,887^{d}$ & 36,362 & 47,112 \\
\hline & & SEM & 1.9 & 0.9 & 6,913 & 4,322 & 5,341 \\
\hline & 16.7 & mean & 72.5 & 10.9 & $42,923^{e}$ & 34,817 & 46,415 \\
\hline & & SEM & 2.6 & 1.3 & 7,137 & 4,980 & 5,857 \\
\hline & 27.8 & mean & 66.8 & 8.8 & nd & nd & nd \\
\hline & & SEM & 3.1 & 2.1 & & & \\
\hline & 55.6 & mean & $62.1^{\mathrm{e}}$ & $7.2^{\mathrm{d}}$ & nd & nd & nd \\
\hline & & SEM & 2.8 & 1.9 & & & \\
\hline \multirow{5}{*}{$\begin{array}{l}\text { DL3-hydroxybutyrate } \\
(\mathrm{mmol} / \mathrm{l})\end{array}$} & & & & & & & \\
\hline & 17.1 & mean & 69.2 & 8.2 & $51,864^{\mathrm{d}}$ & 34,860 & nd \\
\hline & & SEM & 3.1 & 1.9 & 6,128 & 5,105 & \\
\hline & 34.2 & mean & 67.8 & $5.2^{\mathrm{e}}$ & $43,522^{\mathrm{e}}$ & $30,919^{d}$ & nd \\
\hline & & SEM & 4.6 & 1.7 & 6,020 & 5,426 & \\
\hline
\end{tabular}

nd: not done

Expression of results and other abbreviations as in Tables 2 and 3

${ }^{a}$ in these experiments, D glucose and DL3-hydroxybutyrate were added to the medium during the duration of the test

$b$ in these experiments, the cells were preincubated overnight in medium containing $D$ glucose and DL3-hydroxybutyrate, then washed and stimulated by mitogens

c means were calculated on 12 different experiments

d $p<0.05$

e $\mathrm{p}<0.01\}$ when compared with results obtained when D glucose or DL3-hydroxybutyrate was not added to the medium

previously poorly controlled diabetics. Thus the lymphocyte defect is an eminently reversible phenomenon closely linked to the metabolic milieu of the individual.

The data from in vitro experiments confirm the influence of glucose and hydroxybutyrate on lymphocyte markers and mitogen responsiveness. However, such in vitro effects need greater concentrations of these products than those we usually found in our patients. Experiments in which lymphocytes were preincubated in the presence of glucose and DL3hydroxybutyrate, then washed before in vitro stimulation by mitogens, suggest that these products might interfere with the glycosylated receptors for mitogens or with the processes of cell activation.

The demonstration of a normal T-cell status in well controlled JOD does not exclude the possibility of an indirect role of cellular immunity in the mechanism of diabetes. Recent studies [22, 23] suggest that diabetes may be considered as a partially self-supporting disease: hyperglycaemia leads to beta-cell depletion which in turn increases hyperglycaemia. Frequent remissions may occur in recent acute onset juvenile diabetes if this vicious circle is rapidly broken [22]. In the same way, metabolic abnormalities lead to a T-cell defect which in turn may favour the recurrence or the activity of such initial pancreatic aggressors as viruses [1].

Thus, the quest for normoglycaemia in recent insulin dependent juvenile diabetes must be the aim of treatment because long-term complications, completion of beta-cell damage, and defects of cellular immunity are likely to be secondary to disturbed metabolism.

Acknowledgements. To Dr. T. Wilkin for his aid in the preparation of the manuscript.

\section{References}

1. Gamble, D. R., Taylor, K.W., Cumming, H.: Coxsackie viruses and diabetes mellitus. Br. Med. J. 1973 IV, 260-262

2. Bottazzo, G. F., Doniach, D., Pouplard, A.: Humoral autoimmunity in diabetes mellitus. Acta Endocrinol. [Suppl.] (Kbh) 205, 55 (1976)

3. Nerup, J., Andersen, O. O., Bendixen, G., Egeberg, J., Poulsen, J. E.: Antipancreatic cellular hypersensitivity in diabetes. Diabetes 20, 424-427 (1971)

4. Richens, E. R., Ancill, R. J., Gough, K. R., Hartog, M.: Cellular hypersensitivity to mitochondrial antigens in diabetes mellitus. Clin. Exp. Immunol. 13, 1-7 (1973)

5. Maccuish, A. C., Jordan, J., Campbell, C. J., Duncan, L. J. P., Irvine, W. J.: Cell-mediated immunity to human pancreas in diabetes mellitus. Diabetes 23, 693-697 (1974)

6. MacLaren, N. K., Huang, S. W., Taylor, G., Hamilton, B., Cornblath, M.: Circulated antibodies and cytotoxic lymphocyte to cultured human insulinoma in insulin dependent diabetes. Diabetes 24 (Suppl. 2), 401 (1975)

7. Brody, J. L., Merlie, K.: Metabolic and biosynthetic features of lymphocytes from patients with diabetes mellitus. Similarities to lymphocytes in chronic lymphatic leukemia. Br. J. Haematol. 19, 193-201 (1970) 
8. Ragab, A.H., Hazlett, B., Cowan, H. D.: Response of peripheral blood lymphocytes from patients with diabetes mellitus to phyto hemagglutinin and candida albicans antigen. Diabetes 21, 906-907 (1972)

9. Delespesse, G., Duchateau, J., Bastenie, P. A., Lauvaux, J. P., Govaerts, A., Collet, H.: Cell mediated immunity in diabetes mellitus. Clin. Exp. Immunol. 18, 461-467 (1974)

10. MacCuish, A. C., Urbaniak, S. J., Campbell, C. J., Duncan, L. J. P., Irvine, W. J.: Phytohemagglutin transformations and circulating lymphocyte subpopulations in insulin dependent diabetic patients. Diabetes 23, 708-712 (1974)

11. Cattaneo, R., Saibene, V., Pozza, G.: Peripheral T-lymphocytes in juvenile-onset diabetics (JOD) and in maturity onset diabetics (MOD). Diabetes 25, 223-226 (1976)

12. Hann, S., Kaye, R., Falkner, B.: Subpopulations of peripheral lymphocytes in juvenile diabetes. Diabetes 25, 101-103 (1976)

13. Sakaguchi, S., Nakazawa, N., Nakamura, S., Kono, Y., Hazeki, H., Kawa, A.: Cell mediated immunity in diabetes mellitus. In: Abstracts of the 9th Congress of the International Diabetes Federation, New Delhi. Bajaj, J. S. (Ed.), 143. Amsterdam: Excerpta Medica 1976

14. Irvine, W. J.: Classification of idiopathic diabetes. Lancet 1977 I, 638-642

15. Bottazzo, G. F., Doniach, D.: Pancreatic autoimmunity and HLA antigens. Lancet $1976 \mathrm{II}, 800$

16. Mirouze, J., Selam, J. L., Pham, T. C., Cavadore, D.: Evaluation of exogenous insulin hemeostasis by the artificial pancreas in insulin dependent diabetes. Diabetologia 13, 273-278 (1977)

17. Basten, A., Sprent, J., Miller, J. F. A. P.: Receptor for antibody antigen complexes used to separate $\mathrm{T}$-cells from B-cells. Nature 235, 178-180 (1972)
18. Clot, J., Dardenne, M., Brochier, J., Andary, M., Guilhou, J. J.: Evaluation of lymphocyte subpopulations and T-cell functions in psoriasis. Clin. Immunol. Immunopathol. 9, 389-397 (1978)

19. Clot, J., Charmasson, E., Brochier, J.: Age dependent changes of human blood lymphocyte subpopulations. Clin. Exp. Immunol. 32, 346-351 (1978)

20. MacCuish, A., Irvine, W. J.: Autoimmunological aspects of diabetes mellitus. In: Clinics in endocrinology and metabolism. Irvine, W. J. (Ed), vol. 4. London, Philadelphia, Toronto: W. B. Saunders 1975

21. MacCuish, A.: Communication. International Symposium on Immunological aspects of diabetes mellitus. Gentofte, Denmark, 1975. Acta Endocrinol. [Suppl.] (Kbh.) 205, 49-52 (1976)

22. Mirouze, J., Selam, J. L., Pham, T. C., Mendoza, E., Orsetti, A.: Sustained insulin-induced remissions of juvenile diabetes by means of an external artificial pancreas. Diabetologia 14, 223-228 (1978)

23. Turner, R. C., McCarthy, S. T., Holman, R. R., Harris, E.: Beta-cell function improved by supplementing basal insulin secretion in mild diabetes. Br. Med. J. 1976 I, 1252-1254

Received: May 4, 1978, and in revised form: September 7, 1978

Prof. J. Mirouze

Clinique des Maladies Métabolique

et Endocriniennes

Hôpital Saint-Eloi

F-34059 Montpellier Cedex

France 